\title{
Methyl Group Migration During the Fragmentation of Singly Charged Ions of Trimethyllysine-Containing Peptides: Precaution of Using MS/MS of Singly Charged Ions for Interrogating Peptide Methylation
}

\author{
Lei Xiong, Liyan Ping, Bifeng Yuan, and Yinsheng Wang \\ Department of Chemistry, University of California, Riverside, California, USA
}

\begin{abstract}
Core histones are susceptible to a range of post-translational modifications (PTMs), including acetylation, phosphorylation, methylation, and ubiquitination, which play important roles in the epigenetic control of gene expression. Here, we observed an unusual discrepancy between MALDI-MS/MS and ESI-MS/MS on the methylation of trimethyllysine-containing peptides with residues 9-17 from human histone $\mathrm{H3}$ and residues 73-83 from yeast histone H3. It turned out that the discrepancy could be attributed to an unusual methyl group migration from the side chain of trimethyllysine to the C-terminal arginine residue during peptide fragmentation, and this methyl group transfer only occurred for singly charged ions, but not for doubly charged ions. The methyl group transfer argument received its support from the results on the studies of the fragmentation of the ESI- or MALDI-produced singly charged ions of several synthetic trimethyllysine-bearing peptides. The results presented in this study highlighted that caution should be exerted while MS/MS of singly charged ions is employed to interrogate the PTMs of trimethyllysine-containing peptides. (J Am Soc Mass Spectrom 2009, 20, 1172-1181) (C) 2009 American Society for Mass Spectrometry
\end{abstract}

$\mathrm{T}$ The nucleosome core particle consists of a histone octamer around which DNA is wrapped [1]. Two H2A-H2B dimers flank a centrally located (H3$\mathrm{H} 4)_{2}$ tetramer to give the histone octamer [1]. The core histones have a similar structure with a basic N-terminal domain, a globular domain organized by the histone fold, and a C-terminal tail. Core histone N-terminal tails, which emerge from the core particle in all directions, are involved in the establishment of a spectrum of chromatin structural states, while their histone fold domains mediate histone-histone and histone-DNA interactions [1].

The core histones are susceptible to an array of post-translational modifications (PTMs), including acetylation, phosphorylation, methylation, and ubiquitination $[2,3]$. Histone methylation, which occurs on the side chains of lysine and arginine, is the most prominent in histones $\mathrm{H} 3$ and $\mathrm{H} 4$, and it is associated with transcriptional activation, differentiation, imprinting, and $\mathrm{X}$-inactivation [3,4]. In general, methylation at H3-K4, H3-K36, and H3-K79 is associated with euchromatin and gene activation, whereas methylation at $\mathrm{H} 3-\mathrm{K} 9, \mathrm{H} 3-\mathrm{K} 27$, and H4-K20 is involved with hetero-

Address reprint requests to Dr. Y. Wang, Department of Chemistry-027, University of California at Riverdale, 900 University Avenue, Riverdale, CA 92521-0403, USA. E-mail: yinsheng.wang@ucr.edu chromatin and repressed genes. Moreover, histone methylation, together with acetylation and phosphorylation, can form a histone code to provide a "mark" to recruit downstream chromatin assembly or modification proteins for chromatin remodeling and transcription activation $[3,4]$.

MALDI-MS/MS and LC-ESI-MS/MS have been widely used for assessing the PTMs of histones [5, 6]. Together with HPLC separation and enzymatic digestion, they can provide detailed information about the modification sites and levels. Understanding peptide fragmentation is important for investigating the PTMs of proteins by MS/MS with the "bottom-up" strategy. In this context, a protein can be digested to peptides, which can be cleaved by surface-induced dissociation (SID) or collision-induced dissociation (CID) at the amide linkages, to afford a series of $b$ and $y$ ions. The $b$ and y ions are thought to arise from a "charge-directed" pathway where cleavage occurs in the vicinity of a charge site [14]. A "mobile proton transfer" model proposed by Wysocki et al. [7-13] is widely accepted for rationalizing the "charge-directed" fragmentation of peptides, where a proton is transferred from the peptide $\mathrm{N}$ terminus or side chains to the cleavage site [14].

Here, we observed an unusual difference between MALDI- and ESI-MS/MS when analyzing trimethyllysine- 
containing peptides from the Arg-C digestion of histone H3 isolated from cultured human and yeast Saccharomyces cerevisiae (S. cerevisiae) cells. It turned out that a methyl group in trimethyllysine could migrate during the fragmentation of singly charged ions of these peptides, but this migration was not observed for the corresponding doubly charged ions. Based on these findings, we advocate that caution should be exerted while MS/MS of singly charged ions is employed for assessing peptide methylation.

\section{Experimental}

Trimethyllysine-containing synthetic peptides were obtained from Biomatik (Ontario, Canada), and $N^{\mathrm{G}}$ monomethyl-L-arginine was obtained from SigmaAldrich (St. Louis, MO).

\section{Cell Culture and Protein Extraction}

Human HL-60 cells [American Type Culture Collection (ATCC), Manassas, VA] were cultured in RPMI-1640 medium (ATCC) with $10 \%$ FBS at $37^{\circ} \mathrm{C}$ until the cell density reached between $10^{5}$ and $10^{6}$ cells $/ \mathrm{mL}$. Human MCF-7 cells (ATCC) were cultured in DMEM medium (ATCC) with $10 \%$ FBS at $37{ }^{\circ} \mathrm{C}$ until the cells were at $80 \%$ confluence level.

The cells were harvested by centrifugation at 5000 $\mathrm{rpm}$. The cell pellets were subsequently washed with a 5-mL buffer containing $0.25 \mathrm{M}$ sucrose, $0.01 \mathrm{M} \mathrm{MgCl}_{2}$,

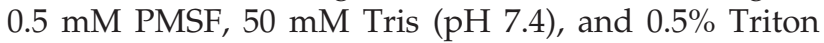
$\mathrm{X}-100$. The cell pellets were then resuspended in $5 \mathrm{~mL}$ of the same buffer and kept at $4{ }^{\circ} \mathrm{C}$ overnight [15]. The histones were extracted from the cell lysis mixture with $0.4 \mathrm{~N}$ sulfuric acid by incubating at $4{ }^{\circ} \mathrm{C}$ for $4 \mathrm{~h}$ with continuous vortexing. The histones in the supernatant were precipitated with cold acetone, centrifuged, dried, and redissolved in water.

Wild-type BY4742 Saccharomyces cerevisiae cells (Open Biosystems, Huntsville, AL) were cultured in a medium containing $1 \%$ yeast extract, $2 \%$ peptone, and $2 \%$ glucose. The cells were harvested when the $\mathrm{OD}_{600}$ reached between 1 and 2 . In this regard, the cells were centrifuged at $5000 \mathrm{rpm}$ at $4{ }^{\circ} \mathrm{C}$ for $10 \mathrm{~min}$, and the resulting cell pellets were washed with sterile water and resuspended in a solution bearing $0.1 \mathrm{mM}$ Tris $(\mathrm{pH}$ 9.4) and $10 \mathrm{mM}$ DTT. The mixture was incubated at $30{ }^{\circ} \mathrm{C}$ for $15 \mathrm{~min}$ with gentle shaking. The cells were recovered by centrifugation and the cell pellets were washed with a solution containing $1.2 \mathrm{M}$ sorbitol and 20 $\mathrm{mM}$ HEPES ( $\mathrm{pH} 7.4$ ), and centrifuged again. The resulting cell pellets were resuspended in the same buffer (50 $\mathrm{mL}$ ) containing 20-30 mg zymolyase and incubated at $30{ }^{\circ} \mathrm{C}$ for $30 \mathrm{~min}$ with gentle shaking to digest the cell wall. Cells were subsequently washed twice with icecold nuclei isolation buffer $(0.25 \mathrm{M}$ sucrose, $60 \mathrm{mM} \mathrm{KCl}$, $14 \mathrm{mM} \mathrm{NaCl}, 5 \mathrm{mM} \mathrm{MgCl} 2,1 \mathrm{mM} \mathrm{CaCl}$, $15 \mathrm{mM}$ MES, $1 \mathrm{mM}$ PMSF, $0.8 \%$ Triton X-100), followed by washing three times with buffer A (10 mM Tris, $\mathrm{pH} 8.0,0.5 \%$
NP-40, $75 \mathrm{mM} \mathrm{NaCl}, 30 \mathrm{mM}$ sodium butyrate, $1 \mathrm{mM}$ PMSF) and twice with buffer B (10 mM Tris, pH 8.0, 0.4 $\mathrm{M} \mathrm{NaCl}, 30 \mathrm{mM}$ sodium butyrate, $1 \mathrm{mM}$ PMSF) [16, 17]. The cell pellets were centrifuged and resuspended, with occasional vortexing, in $0.4 \mathrm{~N}$ sulfuric acid $(3 \mathrm{~mL})$ at $4{ }^{\circ} \mathrm{C}$ for $1 \mathrm{~h}$. The histones in the supernatant were precipitated by cold acetone, centrifuged, dried, and redissolved in water.

\section{Histone H3 Isolation and Digestion}

Histone $\mathrm{H} 3$ was isolated from the core histone mixture by HPLC on an Agilent 1100 system (Agilent Technologies, Palo Alto, CA) and a $4.6 \times 250 \mathrm{~mm} \mathrm{C} 4$ column (Grace Vydac, Hesperia, CA) was used. The flow rate was $0.8 \mathrm{~mL} / \mathrm{min}$, and a 60-min linear gradient of $30 \%-60 \%$ acetonitrile in $0.1 \%$ trifluoroacetic acid (TFA) was employed. Purified histone H3 was digested with sequencing-grade modified Arg-C (Roche Applied Science, Indianapolis, IN) at a protein/enzyme ratio (wt/ wt) of 20:1 in a 100-mM ammonium bicarbonate buffer at $37^{\circ} \mathrm{C}$ overnight. The digested peptides were further separated on the same HPLC system with a Zorbax SB-C18 capillary column $(0.5 \times 150 \mathrm{~mm}, 5 \mu \mathrm{m}$ in particle size, Agilent Technologies), and a 60-min gradient of $2 \%-60 \%$ acetonitrile in $0.6 \%$ acetic acid was used. The flow rate was $10 \mu \mathrm{L} / \mathrm{min}$.

\section{Mass Spectrometry}

MALDI-MS/MS measurements were performed on a QSTAR XL quadrupole/time-of-flight instrument equipped with an o-MALDI ion source (Applied Biosystems, Foster City, CA). The laboratory collision energy applied for MS/MS varied from 50 to $75 \mathrm{eV}$ depending on peptide sequences and modification levels, and the collision gas was nitrogen.

LC-ESI-MS/MS experiments were carried out by coupling directly the effluent from the Zorbax SB-C18 capillary column $(0.5 \times 150 \mathrm{~mm}, 5 \mu \mathrm{m}$ in particle size, Agilent Technologies) to an LTQ linear ion trap mass spectrometer (Thermo Electron Co., San Jose, CA). Isolated peptides were subjected to LC-MS/MS analysis, and we used a $60-$ min linear gradient of $2 \%-60 \%$ acetonitrile in $0.6 \%$ acetic acid delivered by the Agilent 1100 capillary HPLC pump at a flow rate of $6 \mu \mathrm{L} / \mathrm{min}$. MS/MS experiments were carried out in either the data-dependent scan mode or the preselected ion mode. Helium was employed as the collision gas, and the normalized collision energy was 30\%. The width for precursor ion isolation was set at $2.5(\mathrm{~m} / \mathrm{z})$ with an activation $Q$ of 0.25 and an activation time of $30 \mathrm{~ms}$. The spray voltage was $4.5 \mathrm{kV}$, and the temperature for the heated capillary was $275^{\circ} \mathrm{C}$. The $\mathrm{MS}^{3}$ experiments were carried out on the same instrument, where the isolation $\mathrm{Q}$ for the second-stage precursor ion selection was lowered to 0.23 to trap better the low $-m / z$ fragments. 


\section{Results and Discussion}

\section{MALDI-MS/MS Suggests an Unusual} Modification of Pro-16 in Human Histone H3 and the Methylation of Arg-83 in Yeast Histone H3

To assess the PTMs of histone $\mathrm{H} 3$, we extracted the protein from cultured human (HL-60 and MCF-7) and yeast $S$. cerevisiae cells, digested it with Arg-C, and subjected the digestion mixtures to MALDI-MS and MS/MS analyses. The MALDI-MS data showed that the peptide with residues 73-83 in human histone H3 was mostly unmodified, though mono- and dimethylation could also be detected (Figure 1a). The peptide with residues 73-83 from yeast cells as well as the peptide with residues $9-17$ in histone $\mathrm{H} 3$ isolated from human cells were mono-, di- and trimethylated (Figure $1 \mathrm{~b}$ and c). On the other hand, the peptide housing residues 9-17 was predominantly unmodified in
H3 isolated from yeast cells (Figure 1d). In this context, it is worth noting that the ion of $\mathrm{m} / \mathrm{z} 972.6$ in Figure $1 \mathrm{~d}$ is attributed to the protonated ion of another histone H3 peptide, KQLASKAAR, which was supported by MS/MS analysis (spectrum not shown).

MALDI-MS/MS analysis of the trimethylated forms of the two peptides, however, suggests the modifications of Pro-16 and Arg-83 (Figure 2 and Figure 3). In the product-ion spectrum of the $[\mathrm{M}+\mathrm{H}]^{+}$ions of the trimethylated and monoacetylated peptide KSTGGKAPR $(\mathrm{m} / \mathrm{z}$ 984.4, Figure 2$)$, we observed the $\mathrm{b}_{5}+2 \mathrm{Me}, \mathrm{b}_{6}+2 \mathrm{Me}$ $+\mathrm{Ac}$ and $\mathrm{b}_{7}+2 \mathrm{Me}+\mathrm{Ac}$ ions, supporting the dimethylation of Lys-9 and the acetylation of Lys-14. We also observed the neutral loss of an $\mathrm{HN}\left(\mathrm{CH}_{3}\right)_{2}$ from the $\mathrm{b}_{6}+$ $2 \mathrm{Me}+\mathrm{Ac}$ and $\mathrm{b}_{7}+2 \mathrm{Me}+\mathrm{Ac}$ ions, lending further support for the presence of a dimethyllysine in the peptide. The presence of an acetylated lysine in this peptide is
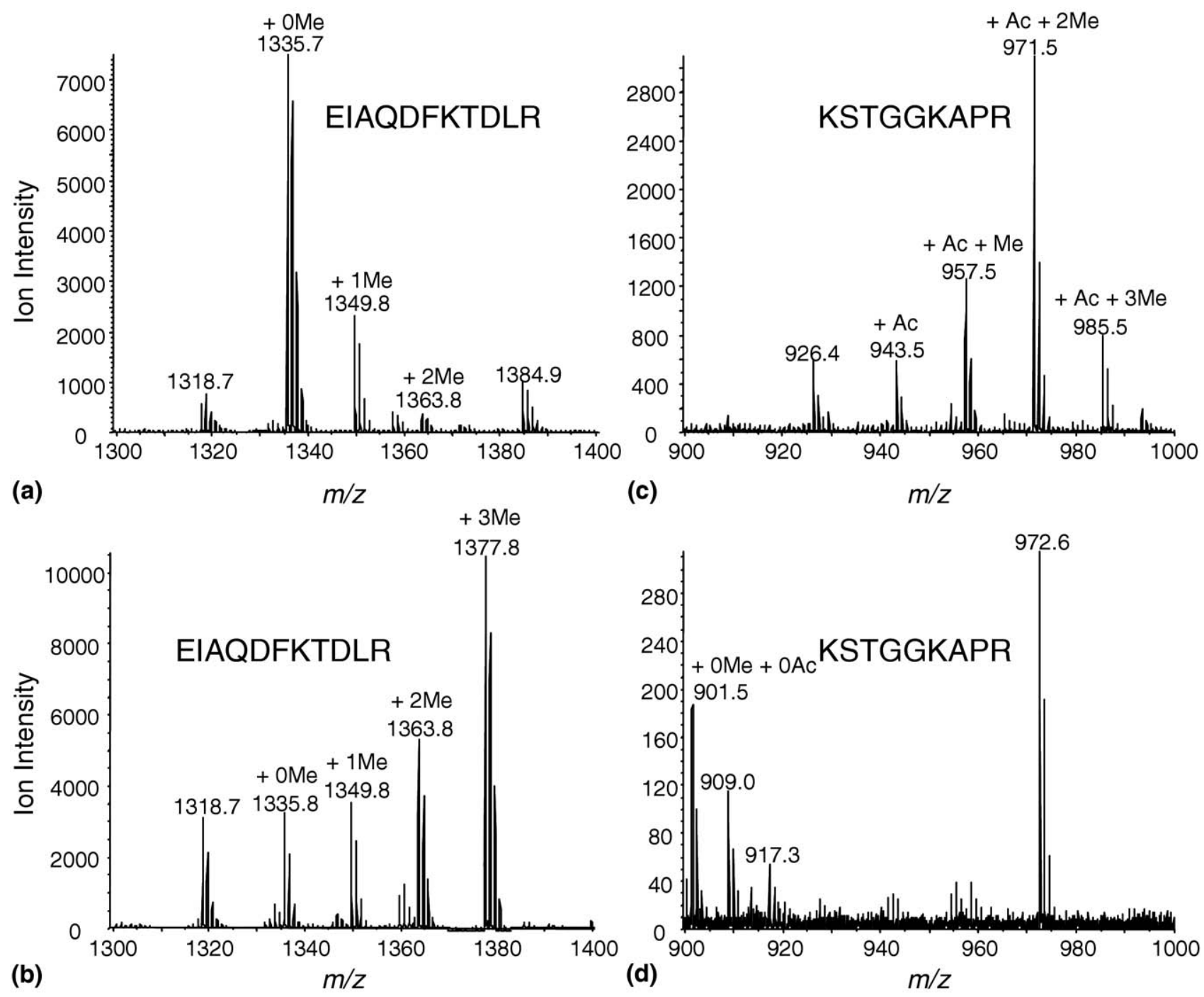

(c)

$m / z$

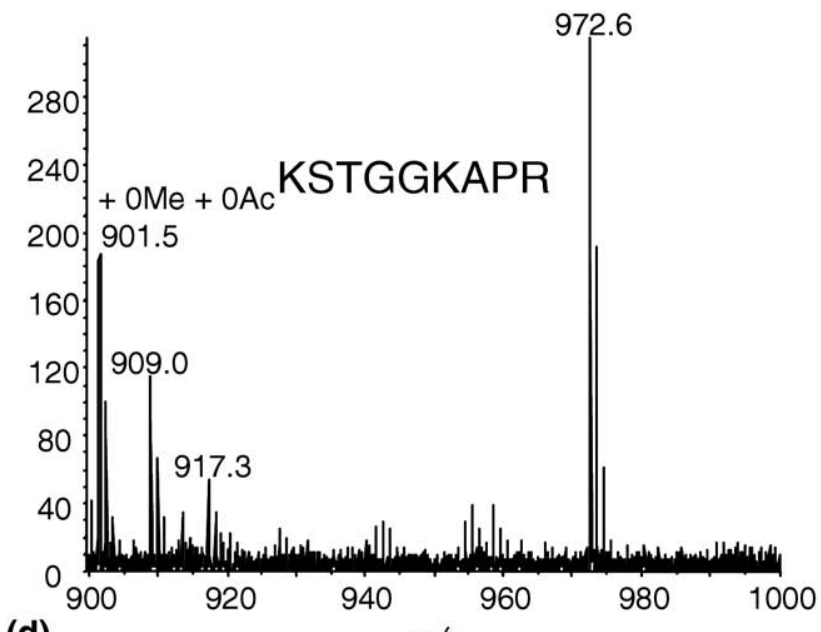

(d)

$m / z$

Figure 1. MALDI-MS of the Arg-C produced peptide with residues 73-83 in histone H3 isolated from MCF-7 human breast cancer cells (a) and yeast cells (b). Shown in (c) and (d) are the MALDI-MS of the Arg-C produced peptide fragment containing residues 9-17 in histone H3 extracted from MCF-7 cells and yeast cells, respectively. 


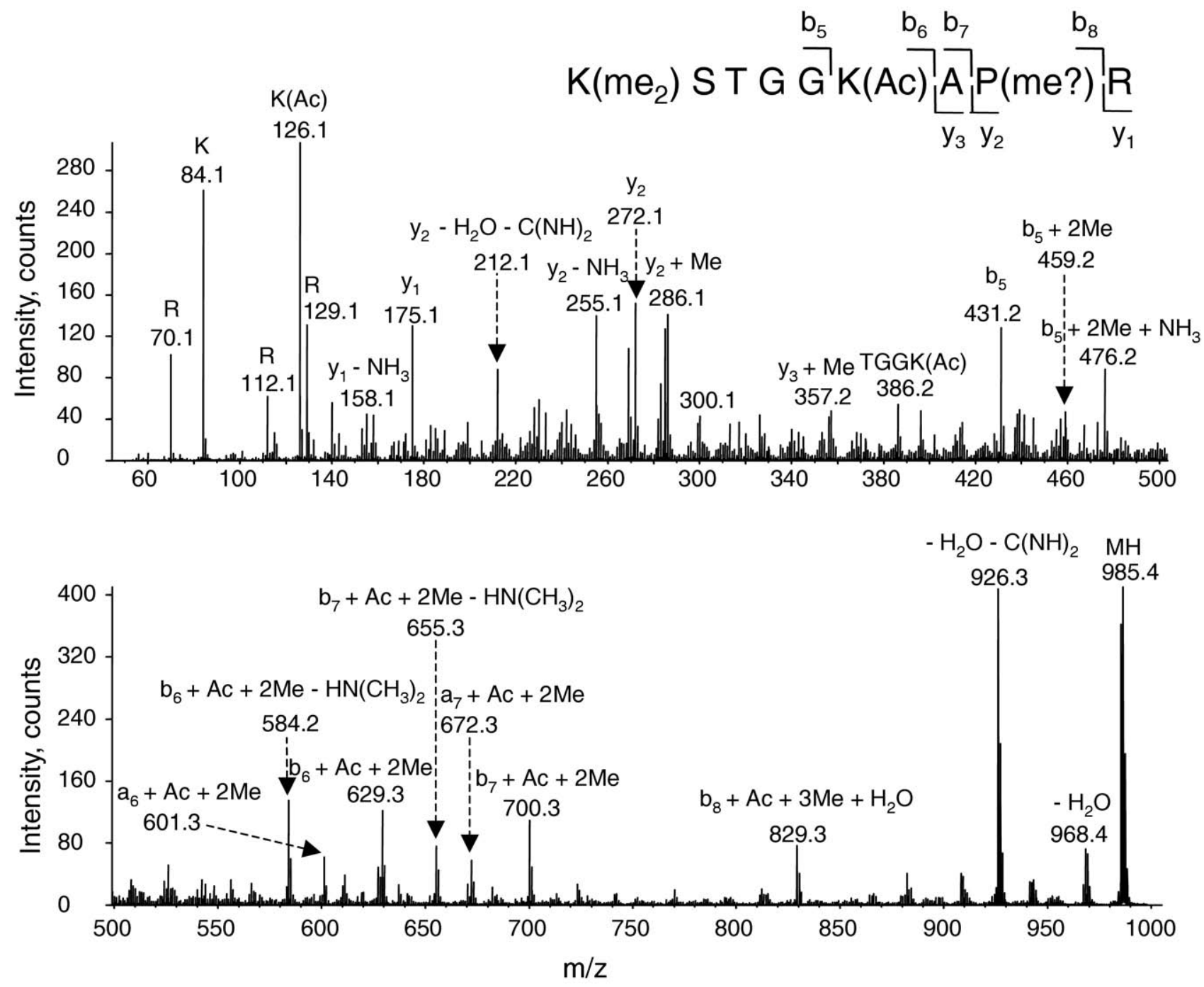

Figure 2. MALDI-MS/MS of the singly charged ion of the peptide with human H3 peptide with residues 9-17 that is monoacetylated and trimethylated $(\mathrm{m} / \mathrm{z}$ 985.5).

also supported by the observation of the diagnostic ion of $\mathrm{m} / \mathrm{z} 126.1$ (Figure 2) [18]. Additionally, the observation of the $y_{2}+M e$ and $y_{3}+$ Me ions and the finding of the $b_{7}+$ $\mathrm{Ac}+2 \mathrm{Me}$ and $\mathrm{b}_{8}+\mathrm{Ac}+3 \mathrm{Me}+\mathrm{H}_{2} \mathrm{O}$ ions suggest that there is a covalent modification of Pro-16 giving rise to a mass increase of $14 \mathrm{Da}$ (Figure 2). Monomethylation can lead to a mass increase of $14 \mathrm{Da}$; however, the methylation of internal proline has not been reported, though methylation of N-terminal proline is known [19].

In the MS/MS of the trimethylated peptide EIAQDFKTDLR ( $\mathrm{m} / \mathrm{z}$ 1377.5, Figure 3, Lys-79 was found to be di- or trimethylated, which is supported by the mass difference between the $\mathrm{y}_{4}$ and $\mathrm{y}_{5}$ ions. A series of $\mathrm{y}_{\mathrm{n}}+\mathrm{Me}$ $(n=1-2)$ and $b_{m}+2 \mathrm{Me}(\mathrm{m}=8-9)$ ions were observed, suggesting that Arg-83 might be partially monomethylated. It is worth noting that the assignments of fragment ions were consistent with exact mass measurements of fragment ions based on the MS/MS acquired on the QSTAR instrument (Table 1).

We also acquired the MALDI-MS/MS of these two peptides bearing lower levels of methylation. Methylation of Pro-16 or Arg-83 could not be detected when the overall methylation level of the peptides dropped. In the MS/MS of the dimethylated peptide with residues 9-17 (Figure S1), which can be found in the electronic version of this article, the presence of the $b_{n}+2 \mathrm{Me}(n=3-8)$ ions supports the dimethylation of Lys-9; the absence of $y_{2}+$ Me and $y_{3}+$ Me ions, along with the presence of $\mathrm{y}_{2}$ and $\mathrm{y}_{3}$ ions, shows that Pro-16 was not modified (Figure S1 and S2 depict the MS/MS in the low $-m / z$ range to better visualize the low-abundance fragments). Together, the above MALDI-MS/MS results suggest that Pro-16 and Arg-83 might be partially modified with a 14-Da mass increase only when these two peptides are trimethylated.

\section{LC-ESI-MS/MS Supports the Absence of Pro-16 and Arg-83 Modification}

To further assess the nature of methylation of the above peptides, we subjected the same trimethylated H3 pep- 


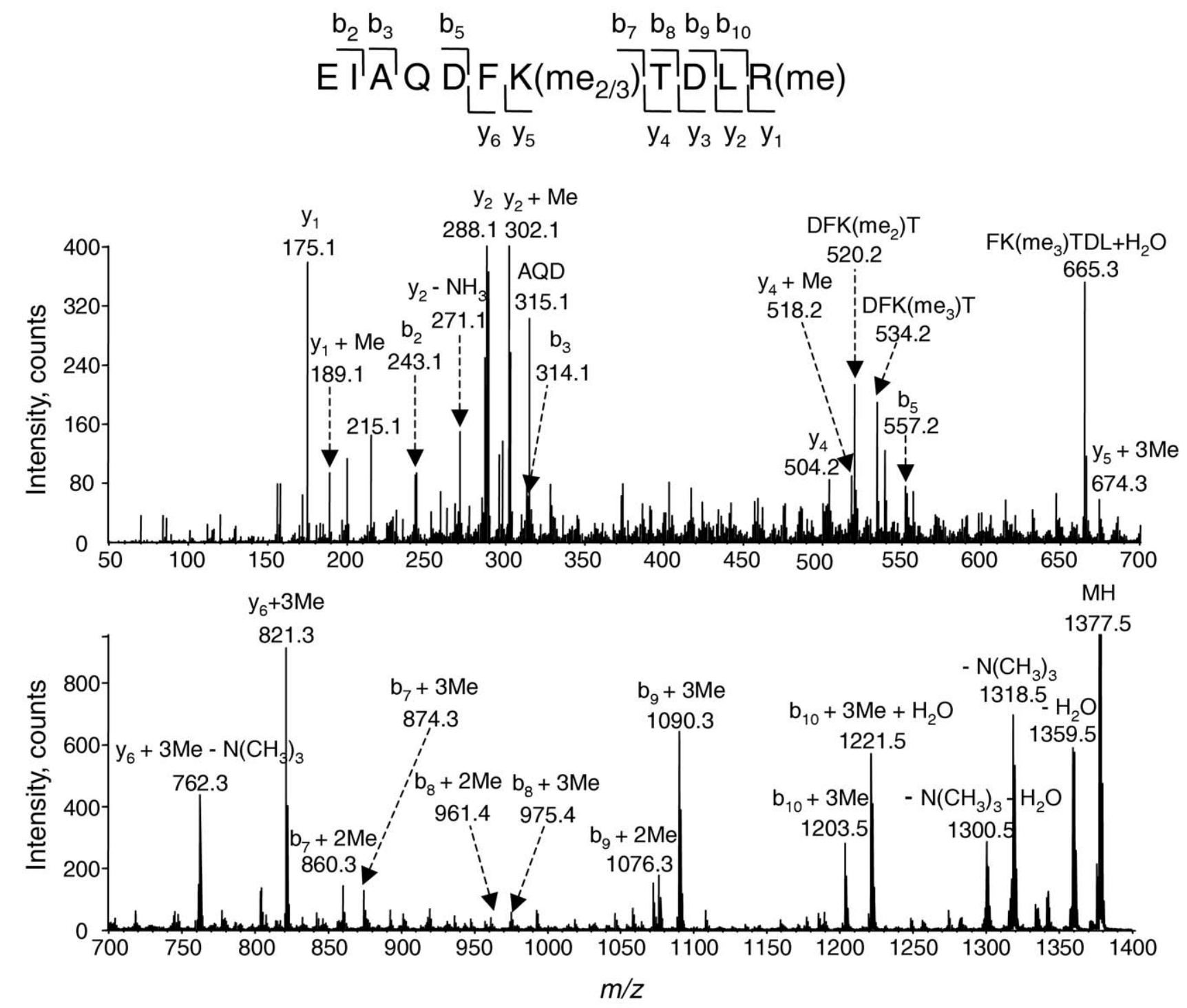

Figure 3. MALDI-MS/MS of the singly charged ion $(\mathrm{m} / \mathrm{z}$ 1377.8) of the trimethylated peptide with residues 73-83 in histone $\mathrm{H} 3$ extracted from $S$. cerevisiae cells.

tides to LC-ESI-MS/MS analyses. Surprisingly, the ESIMS/MS data did not reveal the modification on Pro-16 or Arg-83, instead they only supported the existence of a trimethyllysine in these two peptides (Figure 4).

Unlike the MALDI-MS/MS results, the ESI-MS/MS of the doubly charged $\mathrm{H} 3$ peptide with residues 9-17 showed the formation of $\mathrm{y}_{1}, \mathrm{y}_{2}, \mathrm{y}_{3}$, and $\mathrm{y}_{\mathrm{n}}+$ Ac $(n=$ 4-8) ions, supporting the acetylation of Lys-14 and the lack of modification on Pro-16 (Figure 4a). Additionally, the observation of the neutral loss of a trimethylamine $\left[\mathrm{N}\left(\mathrm{CH}_{3}\right)_{3}\right]$ from both the precursor ion and the $\mathrm{b}_{2}+$ $3 \mathrm{Me}$ ion reveals the trimethylation of Lys-9 (Figure 4a).

ESI-MS/MS of the doubly charged ion of the trimethylated peptide with residues 73-83 of histone H3 isolated from yeast cells also showed the lack of methylation on Arg-83 (Figure 4b), instead the formation of abundant $\mathrm{y}_{2}, \mathrm{y}_{6}+3 \mathrm{Me}, \mathrm{b}_{9}+3 \mathrm{Me}$, and $\mathrm{b}_{10}+3 \mathrm{Me}$ ions supports the trimethylation of Lys-79 and the absence of methylation of Arg-83.
The ESI-MS/MS for the trimethylated peptides supports unequivocally the lysine trimethylation as previously reported $[20,21]$ and the absence of modification on Pro-16 or Arg-83, which is in stark contrast with the MALDI-MS/MS results. However, LC-ESI-MS/MS and MALDI-MS/MS data for these peptides with lower modification levels are consistent, which both supported the methylation of lysine residues alone. The interesting discrepancy between LC-ESI-MS/MS and MALDI-MS/MS on the trimethylated peptides calls for further investigation on the nature of methylation in these peptides.

\section{MS/MS Analyses of Synthetic Trimethyllysine- Containing Peptide EIAQDFK $\left(m_{3}\right)$ TDLR}

To gain insights into the above disagreement between MALDI- and ESI-MS/MS results, we obtained a synthetic trimethyllysine-containing peptide bearing the 
Table 1. A summary of calculated and measured $\mathrm{m} / \mathrm{z}$ of product ions for the trimethylated human $\mathrm{H} 3$ peptide with residues (9-17) and yeast $\mathrm{H} 3$ peptide with residues (73-83). The MS/MS was calibrated by using the $\mathrm{y}_{1}$ and precursor ions as internal references

\begin{tabular}{|c|c|c|c|}
\hline Productions & $\begin{array}{c}\text { Calculated } \\
\mathrm{m} / \mathrm{z}\end{array}$ & $\begin{array}{c}\text { Measured } \\
\mathrm{m} / \mathrm{z}\end{array}$ & $\begin{array}{l}\text { Deviation } \\
\text { (p.p.m.) }\end{array}$ \\
\hline \multicolumn{4}{|l|}{$\mathrm{K}\left(\mathrm{me}_{3}\right) \mathrm{STGGK}(\mathrm{Ac}) \mathrm{APR}$} \\
\hline$y_{2}$ & 272.1717 & 272.1662 & -20 \\
\hline $\mathrm{y}_{2}+\mathrm{Me}$ & 286.1874 & 286.1850 & -8.3 \\
\hline $\mathrm{y}_{2}-\mathrm{NH}_{3}$ & 255.1452 & 255.1448 & -1.5 \\
\hline $\mathrm{Y}_{2}-\mathrm{H}_{2} \mathrm{O}-\mathrm{C}(\mathrm{NH})_{2}$ & 212.1395 & 212.1361 & -16 \\
\hline $\mathrm{y}_{3}+\mathrm{Me}$ & 357.2245 & 357.2157 & -24 \\
\hline$b_{5}$ & 431.2249 & 431.2207 & -9.7 \\
\hline $\mathrm{b}_{5}+2 \mathrm{Me}$ & 459.2562 & 459.2553 & -1.9 \\
\hline $\mathrm{b}_{6}+\mathrm{Ac}+2 \mathrm{Me}$ & 629.3618 & 629.3782 & 26 \\
\hline $\mathrm{b}_{6}+\mathrm{Ac}+2 \mathrm{Me}-\mathrm{HN}\left(\mathrm{CH}_{3}\right)_{2}$ & 584.3039 & 584.3103 & 10 \\
\hline $\mathrm{a}_{6}+\mathrm{Ac}+2 \mathrm{Me}$ & 601.3668 & 601.3788 & 19 \\
\hline$b_{7}+A c+2 M e$ & 700.3989 & 700.4117 & 18 \\
\hline $\mathrm{b}_{7}+\mathrm{Ac}+2 \mathrm{Me}-\mathrm{HN}\left(\mathrm{CH}_{3}\right)_{2}$ & 655.3410 & 655.3570 & 24 \\
\hline $\mathrm{a}_{7}+\mathrm{Ac}+2 \mathrm{Me}$ & 672.4040 & 672.4117 & 11 \\
\hline $\mathrm{b}_{8}+\mathrm{Ac}+3 \mathrm{Me}+\mathrm{H}_{2} \mathrm{O}$ & 829.4778 & 829.4677 & -12 \\
\hline TGGK(Ac) & 386.2034 & 386.2022 & -3.1 \\
\hline $\mathrm{MH}-\mathrm{N}\left(\mathrm{CH}_{3}\right)_{3}$ & 926.5055 & 926.4909 & -15 \\
\hline $\mathrm{MH}-\mathrm{NH}_{3}$ & 968.5524 & 968.5525 & 0.1 \\
\hline \multicolumn{4}{|l|}{$\operatorname{EIAQDFK}\left(\mathrm{me}_{3}\right)$ TDLR } \\
\hline $\mathrm{y}_{1}+\mathrm{Me}$ & 189.1347 & 189.1360 & 6.8 \\
\hline$y_{2}$ & 288.2030 & 288.2006 & -8.3 \\
\hline $\mathrm{y}_{2}+\mathrm{Me}$ & 302.2187 & 302.2220 & 10 \\
\hline$y_{4}$ & 504.2776 & 504.2737 & -7.7 \\
\hline $\mathrm{y}_{4}+\mathrm{Me}$ & 518.2933 & 518.2992 & 11 \\
\hline$y_{5}$ & 632.3726 & 632.3731 & 0.7 \\
\hline $\mathrm{y}_{5}+3 \mathrm{Me}$ & 674.4196 & 674.4253 & 8.4 \\
\hline $\mathrm{y}_{6}+3 \mathrm{Me}$ & 821.4880 & 821.4685 & -24 \\
\hline $\mathrm{Y}_{6}+3 \mathrm{Me}-\mathrm{N}\left(\mathrm{CH}_{3}\right)_{3}$ & 762.4145 & 762.4182 & 4.8 \\
\hline $\mathrm{b}_{2}$ & 243.1339 & 243.1285 & -22 \\
\hline $\mathrm{b}_{8}+2 \mathrm{Me}$ & 961.4990 & 961.4882 & -11 \\
\hline $\mathrm{b}_{8}+3 \mathrm{Me}$ & 975.5147 & 975.4958 & -19 \\
\hline $\mathrm{b}_{9}+2 \mathrm{Me}$ & 1076.5260 & 1076.5250 & -0.9 \\
\hline $\mathrm{b}_{9}+3 \mathrm{Me}$ & 1090.5417 & 1090.5233 & -16 \\
\hline $\mathrm{b}_{10}+2 \mathrm{Me}$ & 1189.6100 & 1189.6324 & 18 \\
\hline $\mathrm{b}_{10}+3 \mathrm{Me}$ & 1203.6257 & 1203.6505 & 20 \\
\hline $\mathrm{b}_{10}+3 \mathrm{Me}+\mathrm{H}_{2} \mathrm{O}$ & 1221.6363 & 1221.6593 & 18 \\
\hline AQD & 315.1299 & 315.1267 & -10 \\
\hline $\mathrm{DFK}\left(\mathrm{me}_{2}\right) \mathrm{T}$ & 520.2766 & 520.2703 & -12 \\
\hline $\mathrm{DFK}\left(\mathrm{me}_{3}\right) \mathrm{T}$ & 534.2923 & 534.2894 & -5.4 \\
\hline $\mathrm{FK}\left(\mathrm{me}_{3}\right) \mathrm{TDL}$ & 665.3869 & 665.3765 & -16 \\
\hline $\mathrm{MH}-\mathrm{N}\left(\mathrm{CH}_{3}\right)_{3}$ & 1318.6638 & 1318.6801 & 12 \\
\hline $\mathrm{MH}-\mathrm{H}_{2} \mathrm{O}$ & 1359.7267 & 1359.7397 & 9.5 \\
\hline
\end{tabular}

same sequence as the yeast $\mathrm{H} 3$ peptide with residues 73-83 and subjected it to MALDI- and ESI-MS/MS analyses. The ESI-MS/MS of this peptide supports the lysine trimethylation (spectrum not shown), which is in keeping with the ESI-MS/MS of the peptide of histone $\mathrm{H} 3$ isolated from yeast cells. Interestingly, the production spectrum of the MALDI-produced singly charged ion of this trimethyllysine-harboring peptide (Figure S3) is almost the same as that of the Arg-C produced peptide from histone $\mathrm{H} 3$ isolated from yeast cells (Figure 3$)$. In this context, we found $y_{n}+\operatorname{Me}(n=1-2)$ and $\mathrm{b}_{\mathrm{m}}+2 \mathrm{Me}(\mathrm{m}=7-9)$ ions, although the C-terminal arginine in this synthetic peptide was not methylated. These results support unambiguously the lack of methylation of Arg-83 in histone $\mathrm{H} 3$ in yeast cells and suggest an unusual fragmentation of the MALDIproduced ions of trimethyllysine-containing peptides. In the latter respect, the above findings suggest that a methyl group may migrate from the side chain of trimethyllysine to the C-terminal side of the peptide during its fragmentation.

\section{Charge State-Specific Migration of Methyl Group for Trimethyllysine-Carrying Peptides}

To assess whether this unusual fragmentation occurs generally for trimethyllysine-containing peptides, we further obtained two synthetic, alanine-rich, and trimethyllysine-containing peptides, AAAK $\left(\mathrm{me}_{3}\right) \mathrm{AAK}$ and AAAK $\left(\mathrm{me}_{3}\right) \mathrm{AAR}$, and subjected them to MALDIand ESI-MS/MS analyses. ESI-MS/MS of the doubly charged ions of the two peptides confirmed unambiguously the trimethylation of the central lysine residue in the peptide, as manifested by the observation of $b_{n}(n=$ $2-3), b_{m}+3 \mathrm{Me}(\mathrm{m}=4-6), \mathrm{y}_{\mathrm{x}}(\mathrm{x}=1-3)$, and $\mathrm{y}_{5}+3 \mathrm{Me}$ ions (Figure S4a and $\mathrm{b})$. However, ions arising from methyl group migration, i.e., $\mathrm{b}_{\mathrm{m}}+2 \mathrm{Me}(\mathrm{m}=4-6)$ or $\mathrm{y}_{\mathrm{x}}+$ Me $(x=1-3)$, could not be detected in either spectrum.

By contrast, fragment ions emanating from the methyl group migration could be readily observed in the MS/MS of the singly charged ions of the two peptides produced by either MALDI or ESI (Figure 5 shows the ESI-MS/MS results). For instance, we observed $\mathrm{y}_{\mathrm{n}}+\mathrm{Me}(n=1-3)$ and $\mathrm{a}_{\mathrm{m}}+2 \mathrm{Me} / \mathrm{b}_{\mathrm{m}}+2 \mathrm{Me}$ $(\mathrm{m}=4-6)$ ions in the MS/MS of the ESI-produced singly charged ion of $\mathrm{AAAK}\left(\mathrm{me}_{3}\right) \mathrm{AAR}$ (Figure 5a). While the above $a_{m}+2 M e / b_{m}+2 M e$ ions could be observed in the corresponding spectrum of AAAK $\left(\mathrm{me}_{3}\right) \mathrm{AAK}$, the $\mathrm{y}_{\mathrm{n}}+\mathrm{Me}(n=1-3)$ ions are barely detectable (Figure $5 b$ ). The different basicities of lysine and arginine, which reside on the C-termini of these two synthetic peptides, may account for their different susceptibilities in the formation of $\mathrm{y}$ and $\mathrm{y}+\mathrm{Me}$ ions. The MALDI-MS/MS of the singly charged ions of the two peptides gave similar results (Data not shown). Together, the above results demonstrated that the interesting methyl group migration could only be observed in the MS/MS of the singly-charged ions of trimethyllysine-containing peptides, regardless of whether the precursor ions are produced by MALDI or ESI.

To further examine the destination of the migrated methyl group, we acquired the $\mathrm{MS}^{3}$ data, which record the product ions formed from the cleavages of the $y_{1}+$ $\mathrm{Me}, \mathrm{y}_{2}+\mathrm{Me}$, and $\mathrm{y}_{3}+$ Me ions observed in Figure $5 \mathrm{a}$. As depicted in Figure 6a, the product-ion spectrum emanating from the fragmentation of the $\mathrm{y}_{1}+$ Me ion gives the neutral losses of $\mathrm{NH}_{3}(m / z 172)$, methylamine $\left(\mathrm{CH}_{3} \mathrm{NH}_{2}, \mathrm{~m} / \mathrm{z}\right.$ 158), and monomethylcarbodiimide $\left(\mathrm{HN}=\mathrm{C}=\mathrm{NCH}_{3}, m / z\right.$ 133). The latter two are characteristic neutral losses for the protonated ions of peptides 

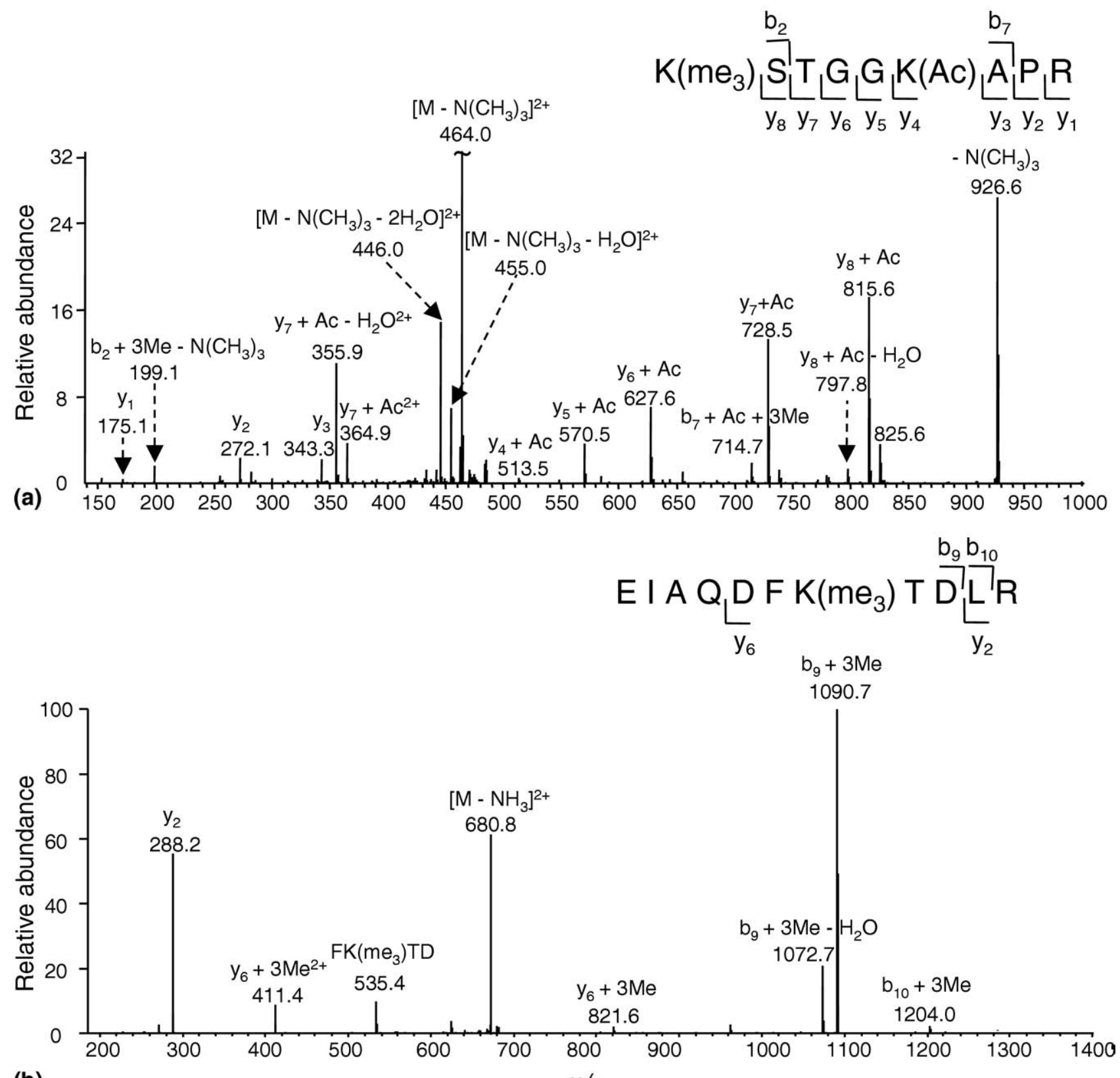

(b)

Figure 4. MS/MS of the ESI-produced doubly charged ions of trimethylated peptides with residues 9-17 in histone H3 isolated from MCF-7 cells (a) and with residues 73-83 in histone H3 extracted from S. cerevisiae cells $(\mathbf{b})$.

housing an $N^{\mathrm{G}}$-monomethyl-L-arginine [22-24]. Indeed the $\mathrm{MS}^{3}$ arising from the further cleavage of $\mathrm{y}_{1}+\mathrm{Me}$ ion shows the formation of all fragment ions that can be found in the product-ion spectrum of the $[\mathrm{M}+\mathrm{H}]^{+}$ion of standard $N^{\mathrm{G}}$-monomethyl-L-arginine (Figure 6a and Figure S5). This result supports that the methyl group in the side-chain of a trimethyllysine side chain can be migrated to the guanidinium group of arginine. Aside from those ions that can be found in the MS/MS of the standard $N^{\mathrm{G}}$-monomethyl-L-arginine, the $\mathrm{MS}^{3}$ reveals the formation of three unique fragment ions, i.e., the ions of $m / z 157,130$, and 60 . The former two ions are attributed to the neutral loss of a $\mathrm{CH}_{3} \mathrm{OH}$ and the combined neutral losses of $\mathrm{NH}_{3}$ and $\mathrm{HN}=\mathrm{C}=\mathrm{NH}$, respectively, whereas the ion of $\mathrm{m} / \mathrm{z} 60$ is attributed to the protonated ion of the guanidinium moiety of arginine. The formation of these three ions is consistent with the view that a portion of the $y_{1}+$ Me ion carries the methyl group on the C-terminal carboxylic acid functionality. The relatively low abundances of these three fragment ions suggest that the methyl group in $\mathrm{y}_{1}+$ Me ion resides mainly on the guanidinium portion of arginine.

The $\mathrm{MS}^{3}$ of the $\mathrm{y}_{2}+$ Me and $\mathrm{y}_{3}+$ Me ions both revealed the formation of abundant $\mathrm{y}_{1}+\mathrm{Me}(\mathrm{m} / \mathrm{z} 189)$ and $\mathrm{y}_{1}+$ 


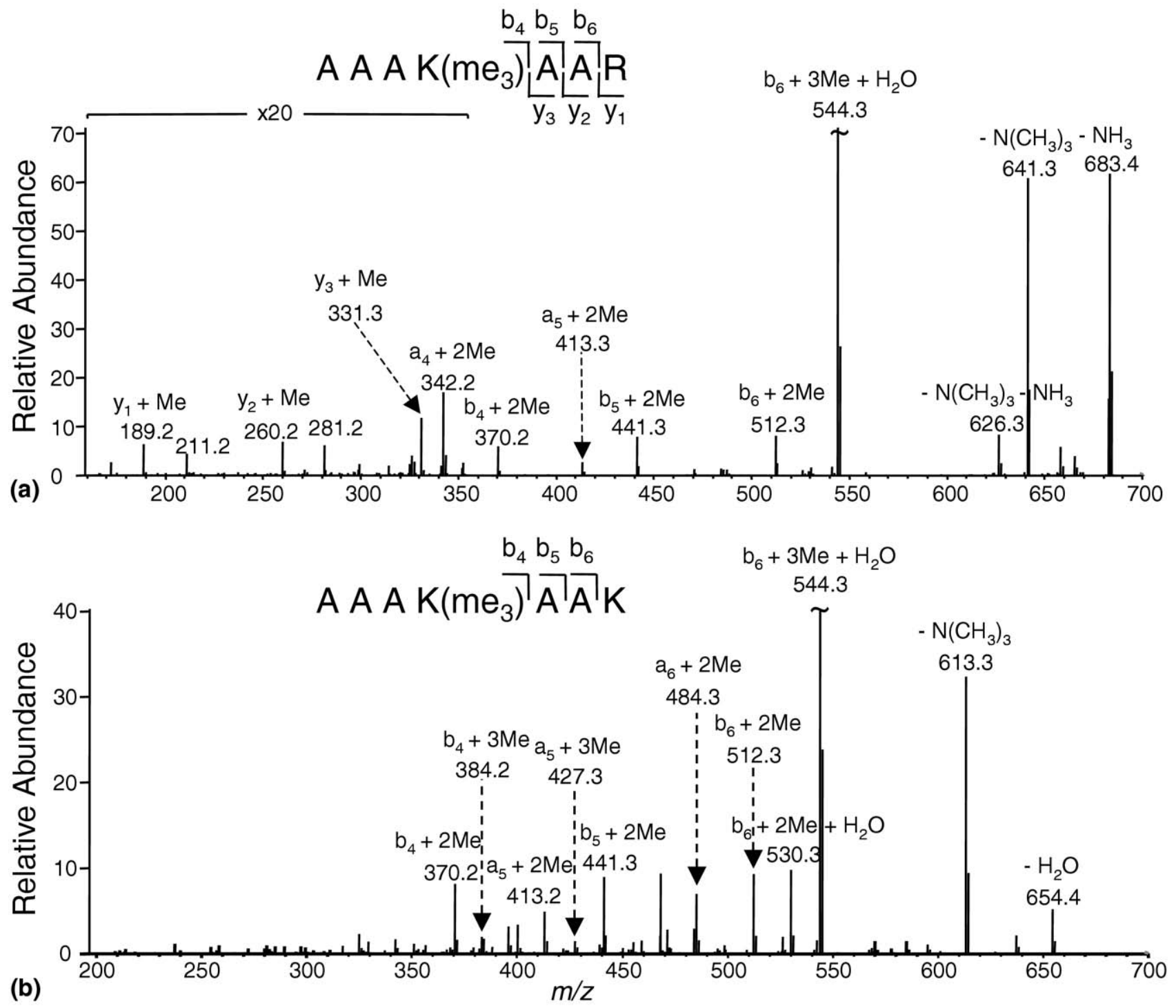

Figure 5. MS/MS of the ESI-produced singly charged ions of the synthetic, trimethyllysine-bearing peptides AAAK $\left(\mathrm{me}_{3}\right) \mathrm{AAR}\left(\mathrm{m} / z\right.$ 700.5) (a) and AAAK $\left(\mathrm{me}_{3}\right) \mathrm{AAK}(\mathrm{m} / z$ 672.5) (b).

Me- $\mathrm{NH}_{3}\left(m / z\right.$ 172) ions, whereas the unmethylated $\mathrm{y}_{1}$ ion was not detectable (Figure $6 \mathrm{~b}$ and $\mathrm{c}$ ), strongly suggesting that in these two fragment ions, the methyl group is located on the C-terminal arginine residue. It is worth noting that the above $\mathrm{MS}^{3}$ results also lend further support of our assignments of the $y_{\mathrm{n}}+\operatorname{Me}(n=$ 1-3) ions observed in Figure 5a.

During the fragmentation of protonated ions of peptides induced by CID or SID, a "mobile proton" can be transferred to the amide linkage to induce the formation of the $b$ and its complementary $y$ ions [7-13]. This model is successful in rationalizing the formation of $b$ and $y$ ions and the preference of specific chain cleavage sites during the CID or SID of peptides through the "charge directed" pathway. Here we showed that, during the collisional activation of the singly charged, trimethyllysine-harboring peptides, regardless of whether the ion is produced by MALDI or ESI, a methyl group can migrate from the side-chain of a trimethyllysine to the guanidinium side-chain or the carboxylic acid moiety of the C-terminal arginine. This methyl group migration does not occur during the fragmentation of the ESI-produced doubly charged ions of trimethyllysine-containing peptides.

The difference between MALDI-MS/MS and LCESI-MS/MS results on the tri-methylated peptides with residues 9-17 and 73-83 is attributed to the peptide charge difference. While the MALDI-produced ions of these peptides carry only one charge, the ESI-formed doubly charged ions of these two peptides adopt a protonated side chain or $\mathrm{N}$-terminus other than the charge located on the side-chain of the trimethylated lysine residue. These protons are mobile, thereby fulfilling the requirement for the "charge-directed" pathway. Peptide 

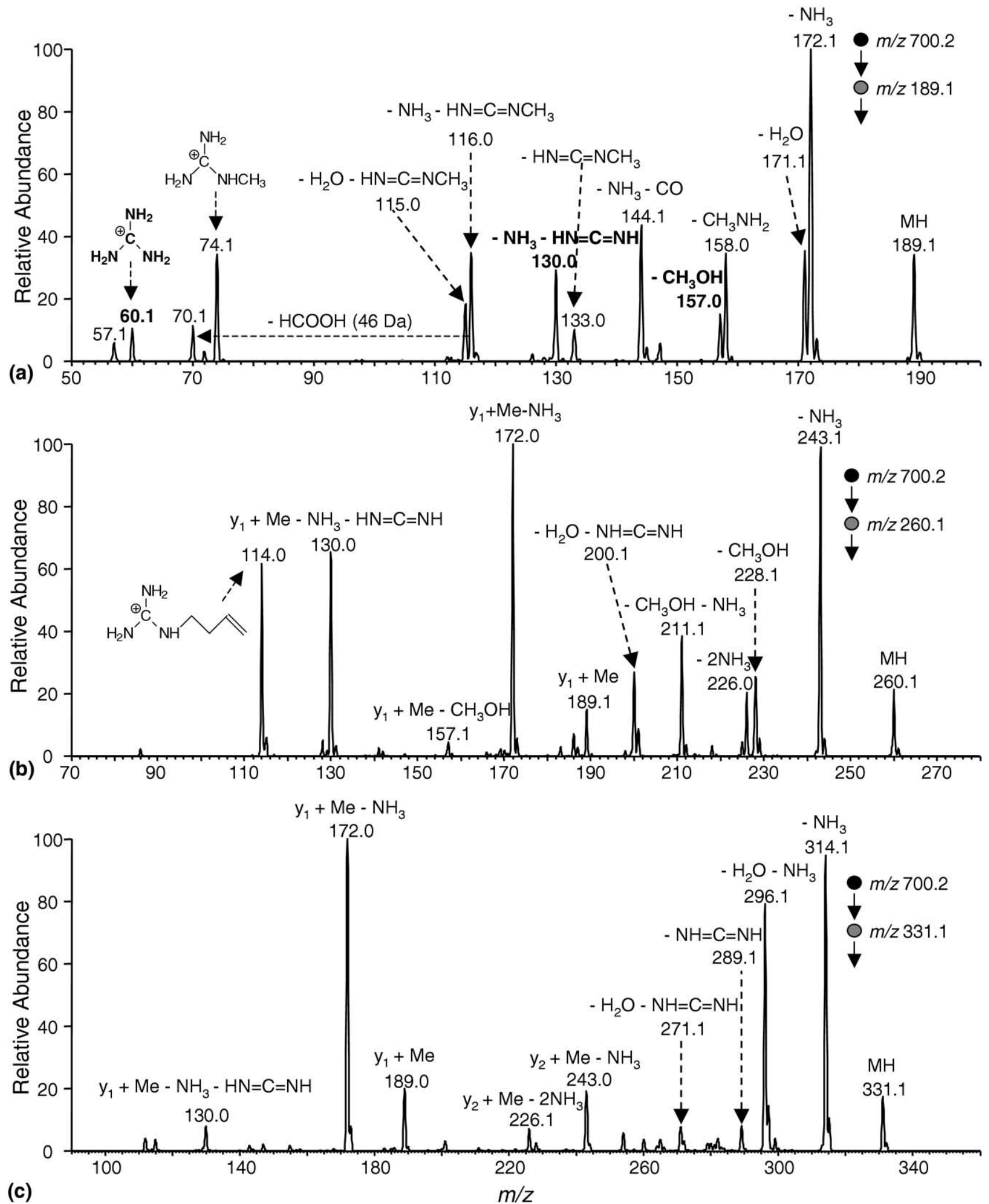

Figure 6. $\mathrm{MS}^{3}$ monitoring the fragmentation of the $\mathrm{y}_{1}+\mathrm{Me}(\mathbf{a}), \mathrm{y}_{2}+\mathrm{Me}(\mathbf{b})$, and $\mathrm{y}_{3}+\mathrm{Me}(\mathbf{c})$ ions observed in Figure 5a. In Figure 6a, the three fragment ions that were not observed in the MS/MS of the $[\mathrm{M}+\mathrm{H}]^{+}$ion of $\mathrm{N}^{\mathrm{G}}$-monomethyl-L-arginine (Figure S5) are labeled in bold fonts.

bond cleavage arising from the mobile proton transfer is likely to be energetically more favorable than the methyl group migration. Thus, we did not observe fragment ions emanating from the methyl group transfer in the MS/MS of the ESI-produced doubly charged ions of the trimethyllysine-containing peptides. 
MALDI-MS/MS and LC-ESI-MS/MS for the peptides with lower methylation level are consistent because these peptides carry a "mobile" proton to facilitate the fragmentation, as observed for the fragmentation of the ESIproduced doubly charged ions of the trimethyllysinehousing peptides where the transfer of a mobile proton takes place. It is worth emphasizing that the methyl group migration is not essential for the fragmentation of trimethylated lysine-containing peptides. The formation of $y_{n}$ ( $n=1,2$ in Figures 2, 3, and S3) ions supports that the cleavage of amide bonds can occur in the absence of methyl group transfer.

\section{Conclusions}

We observed an interesting methyl group transfer phenomenon during the fragmentation of singly charged ions of trimethyllysine-containing peptides; a methyl group on the side chain of trimethyllysine can be transferred to the C-terminal residue of the peptide before amide bond cleavage. The results from the present study call for special attention to the possibility of this type of methyl group migration while MS/MS of singly charged ions is employed to interrogate the methylation of proteins, including histones.

\section{Acknowledgment}

This work was supported by the National Institutes of Health (R01 CA116522).

\section{Appendix A Supplementary Material}

Supplementary material associated with this article may be found in the online version at doi:10.1016/ j.jasms.2009.02.014.

\section{References}

1. Luger, K.; Mader, A. W.; Richmond, R. K.; Sargent, D. F.; Richmond, T. J. Crystal Structure of the Nucleosome Core Particle at 2.8 A Resolution. Nature 1997, 389, 251-260.

2. Strahl, B. D.; Allis, C. D. The Language of Covalent Histone Modifications. Nature 2000, 403, 41-45.

3. Jenuwein, T.; Allis, C. D. Translating the Histone Code. Science 2001, 293, 1074-1080.

4. Klose, R. J.; Zhang, Y. Regulation of Histone Methylation by Demethylimination and Demethylation. Nat. Rev. Mol. Cell. Biol. 2007, 8, 307-318.

5. Cocklin, R. R.; Wang, M. Identification of Methylation and Acetylation Sites on Mouse Histone H3 Using Matrix-Assisted Laser Desorption/
Ionization Time-of-Flight and Nanoelectrospray Ionization Tandem Mass Spectrometry. J. Protein Chem. 2003, 22, 327-334.

6. Zhang, K.; Williams, K. E.; Huang, L.; Yau, P.; Siino, J. S.; Bradbury, E. M.; Jones, P. R.; Minch, M. J.; Burlingame, A. L. Histone acetylation and deacetylation: Identification of acetylation and methylation sites of HeLa histone H4 by mass spectrometry. Mol. Cell. Proteom. 2002, 1, 500-508.

7. Gu, C.; Tsaprailis, G.; Breci, L.; Wysocki, V. H. Selective Gas-Phase Cleavage at the Peptide Bond C-Terminal to Aspartic Acid in FixedCharge Derivatives of Asp-Containing Peptides. Anal. Chem. 2000, 72, 5804-5813.

8. Tsaprailis, G.; Nair, H.; Somogyi, A.; Wysocki, V. H.; Zhong, W. Q.; Futrell, J. H.; Summerfield, S. G.; Gaskell, S. J. Influence of Secondary Structure on the Fragmentation of Protonated Peptides. J. Am. Chem. Soc. 1999, 121, 5142-5154.

9. Nair, H.; Wysocki, V. H. Are Peptides Without Basic Residues Protonated Primarily at the Amino Terminus? Int. J. Mass Spectrom. 1998, 174, 95-100.

10. Dongre, A. R.; Somogyi, A.; Wysocki, V. H. Surface-Induced Dissociation: An Effective Tool to Probe Structure, Energetics, and Fragmentation Mechanisms of Protonated Peptides. J. Mass Spectrom. 1996, 31, 339-350.

11. McCormack, A. L.; Somogyi, A.; Dongre, A. R.; Wysocki, V. H Fragmentation of Protonated Peptides: Surface-Induced Dissociation in Conjunction with a Quantum Mechanical Approach. Anal. Chem. 1993, $65,2859-2872$.

12. Tsaprailis, G.; Somogyi, A.; Nikolaev, E. N.; Wysocki, V. H. Refining the Model for Selective Cleavage at Acidic Residues in Arginine-Containing Protonated Peptides. Int. J. Mass Spectrom. 2000, 196, 467-479.

13. de Maaijer-Gielbert, J.; Gu, C.; Somogyi, A.; Wysocki, V. H.; Kistemaker P. G.; Weeding, T. L. Surface-Induced Dissociation of Singly and Multiply Protonated Polypropylenamine Dendrimers. J. Am. Soc. Mass Spectrom. 1999, 10, 414-422.

14. Paizs, B.; Suhai, S. Fragmentation Pathways of Protonated Peptides Mass Spectrom. Rev. 2005, 24, 508-548.

15. Zhang, K.; Tang, H.; Huang, L.; Blankenship, J. W.; Jones, P. R.; Xiang F.; Yau, P. M.; Burlingame, A. L. Identification of Acetylation and Methylation Sites of Histone H3 from Chicken Erythrocytes by HighAccuracy Matrix-Assisted Laser Desorption Ionization-Time-of-Flight, Matrix-Assisted Laser Desorption Ionization-Postsource Decay, and Nanoelectrospray Ionization Tandem Mass Spectrometry. Anal. Biochem. 2002, 306, 259-269.

16. Edmondson, D. G.; Smith, M. M.; Roth, S. Y. Repression Domain of the Yeast Global Repressor Tup1 Interacts Directly with Histones H3 and H4. Genes Dev. 1996, 10, 1247-1259.

17. Braunstein, M.; Rose, A. B.; Holmes, S. G.; Allis, C. D.; Broach, J. R. Transcriptional Silencing in Yeast is Associated with Reduced Nucleosome Acetylation. Genes Dev. 1993, 7, 592-604.

18. Margueron, R.; Trojer, P.; Reinberg, D. The Key to Development: Interpreting the Histone Code? Curr. Opin. Genet. Dev. 2005, 15, 163-176.

19. Stock, A.; Clarke, S.; Clarke, C.; Stock, J. N-Terminal Methylation of Proteins: Structure, Function, and Specificity. FEBS Lett. 1987, 220, 8-14.

20. Miao, F.; Natarajan, R. Mapping Global Histone Methylation Patterns in the Coding Regions of Human Genes. Mol. Cell. Biol. 2005, 25, 46504661 .

21. Zhang, K.; Sridhar, V. V.; Zhu, J.; Kapoor, A.; Zhu, J. K. Distinctive Core Histone Post-Translational Modification Patterns in Arabidopsis thaliana. PLOS ONE 2007, 2, e1210.

22. Thorne, G. C.; Gaskell, S. J. Elucidation of Some Fragmentations of Small Peptides Using Sequential Mass Spectrometry on a Hybrid Instrument. Rapid Commun. Mass Spectrom. 1989, 3, 217-221.

23. Zou, Y.; Wang, Y. Tandem Mass Spectrometry for the Examination of the Post-Translational Modifications of High-Mobility Group A1 Proteins: Symmetric and Asymmetric Dimethylation of Arg25 in HMGA1a Protein. Biochemistry 2005, 44, 6293-6301.

24. Zou, Y.; Webb, K.; Perna, A. D.; Zhang, Q.; Clarke, S.; Wang, Y. A Mass Spectrometric Study on the In Vitro Methylation of HMGA1a and HMGA1b Proteins by PRMTs: Methylation Specificity, the Effect of Binding to AT-Rich Duplex DNA, and the Effect of C-Terminal Phosphorylation. Biochemistry 2007, 46, 7896-7906. 